\title{
AFFORDABLE HOUSING AND DIVERSITY IN VANCOUVER
}

\author{
Abigail Bond
}

\section{How Vancouver's Housing Affordability Crisis Impacts Its Diversity}

Responding to Vancouver's housing crisis and maintaining its unique and vibrant diversity are the most significant challenges facing the City today. Vancouver's housing affordability crisis is being mirrored in many cities around the world and is in part the result of pressure on the housing market created by the global flow of money, people and jobs. Responding to this crisis is the most significant challenge facing the City today - with Vancouver residents facing among the highest rents and housing purchase prices, but lowest median incomes among Canadian cities (CMHC, 2016a). This is a crisis situation experienced by many households across a broad range of incomes, but impacting low-income, vulnerable, and marginalized households most significantly. Affordable homes are foundational for a growing City, and are essential if diverse households, made up of people from all incomes and backgrounds, are able to form or arrive, and stay to make a future in Vancouver. The crisis is resulting in many people making the difficult choice to leave the City in order to find an adequate, suitable, and affordable home where they can thrive.

Like other global cities, Vancouver's middle-income households are also now experiencing challenges with securing and keeping an affordable home in the City, often having to make difficult choices about what to spend their income on. The high cost of renting in relation to income and very limited availability of rental housing, with a vacancy rate of below $1 \%$, limits the housing choices and increases competition for both low- and middle-income households. Housing affordability is a general measure defined by Canada Mortgage and Housing Corporation as a share of household gross income of $30 \%$ on rental shelter costs, and no more than $32 \%$ of gross household income on homeownership. Using this measure, cities such as Toronto and Vancouver have over one-third of their households facing affordability problems, while in Calgary and Edmonton the share is one-fifth (Figure 3.1). The situation for renters, most of them in the private non-regulated market, is much more stressful. Paying any more than $30 \%$ of your income on rent, your other spending choices are compromised; paying more than $50 \%$, you are in danger of losing your home and experiencing homelessness. In Vancouver, the share of renter households paying more than $30 \%$ of their income in shelter costs has increased steadily in the last 15 years as the data in Figure 3.2 demonstrate. Close to 46,000 Vancouver renters are paying more than $30 \%$ of their income on rent, and of these 15,000 renter households are paying more than 50\% of their income on rent (Statistics Canada, 2017a). 


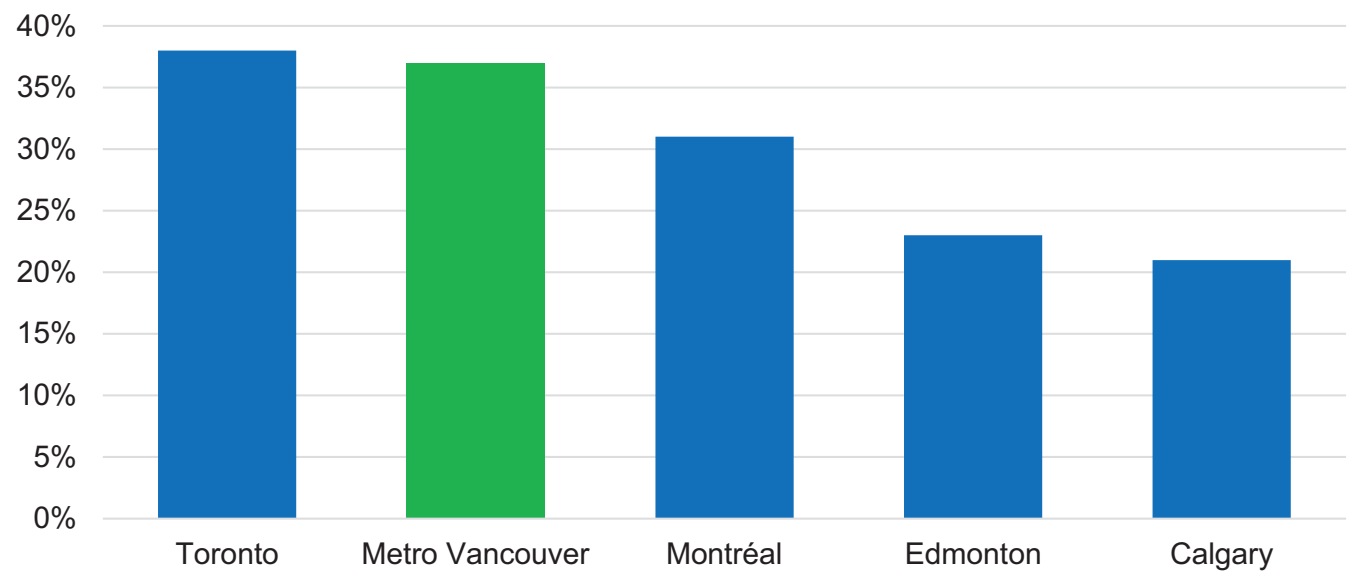

FIGURE 3.1 Share of Households Spending 30\% or More on Shelter Costs, 2016.

Source: Statistics Canada, 2017b.

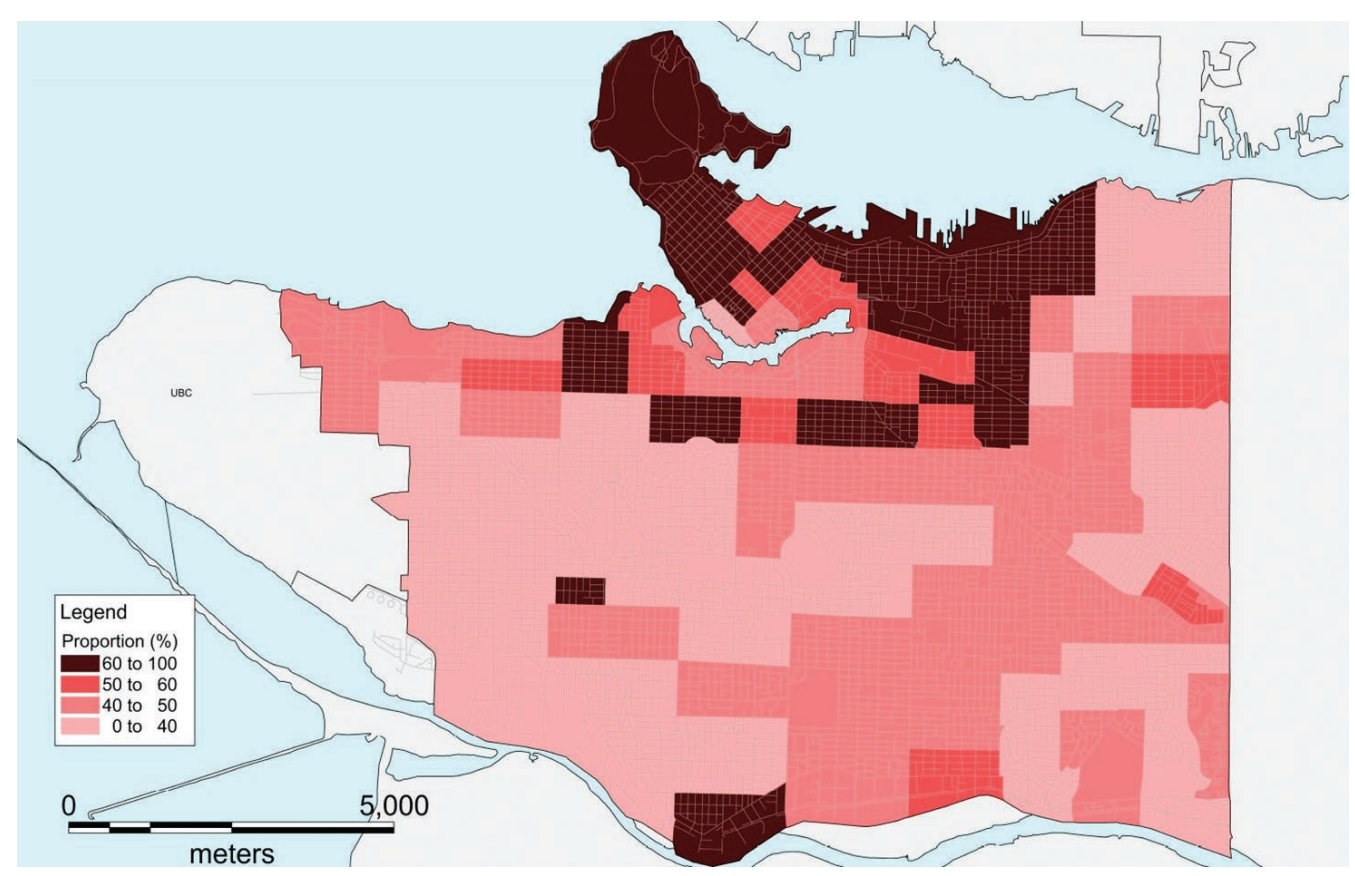

FIGURE 3.2 Spatial Distribution of Vancouver Households Spending 30\% or More on Shelter. Source: City of Vancouver, based on Statistics Canada, Census of the Population, 2017a.

The increase in numbers of those paying too much of their income has expanded the housing crisis to middle-income households, and now puts a much larger range of households at risk of not being able to afford to stay in Vancouver, including workers, immigrants, families, artists, young people, and students (CMHC, 2016b). Young households and families aged between 20 and 40 are struggling to find a way to stay, despite it being an initially attractive place to study 
and start their careers. Generation Squeeze is an advocacy and research group. It has shown how it takes 29 years of full-time work for a typical young person to save a $20 \%$ down payment on an average-priced home -23 more years than when today's ageing population started out as young people (Generation Squeeze, 2019). Thus, the same age group now has far less opportunity to live in a secure, affordable home and accumulate wealth. Many are forced to live with parents, rent for longer, or even leave.

The high cost and limited availability of renting and the growing inaccessibility of homeownership, combined with childcare costs, make it difficult for these households to stay in the City for a long-term. The last census showed that number of children aged 0 -four years had declined by 1\% since 2011 (Statistics Canada, 2017a). This puts our healthy and growing economy and communities at risk, as many mid-career workers see little options but to leave Vancouver. This impacts companies who lose key workers critical to their business, and communities lose families and children as a result.

\section{The Intersection of Housing Unaffordability with Characteristics of Diverse Households}

There are multiple and often intersecting characteristics of household diversity, including income, family make-up, and race to name a few. Diverse households make Vancouver both vibrant and unique, but this diversity is being placed at risk by the current housing crisis and the long-standing and systemic inequities that exist in our City. The intersection between housing affordability challenges and marginalization, including gender and sexual identity, race, poverty, family status, and mental and physical health, has become a powerful force limiting inclusion, diversity and mixed communities in our City. The lack of housing affordability affects many people in our City, but it is more likely to affect you, if you are also a member of a marginalized group. In Shaping Futures Changing the Housing Story, Chisholm and Hulchanski state that we need to reframe our understanding of the important role housing plays in our economy, in reducing carbon, in social inclusion, and in inequality (Chisholm and Hulchanski, 2019) (Figure 3.3).

80,050

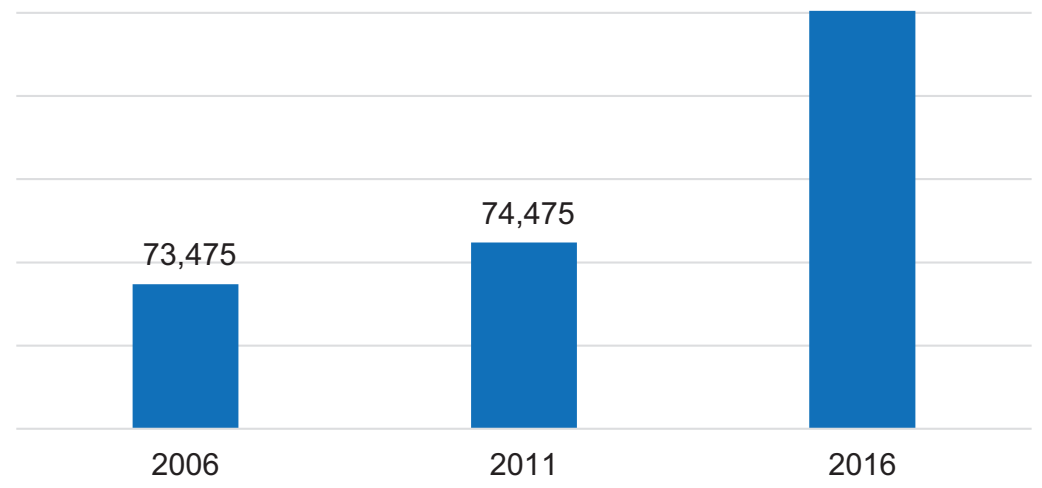

FIGURE 3.3 Renter Households Spending 30\% or More on Shelter, 2006-2016.

Source: Statistics Canada, Census 2006, 2016, and National Household Survey 2011. 
One example is the intersection between the lack of housing affordability and gender, as $35 \%$ of lone-parent families are considered to be low-income compared to $15 \%$ of households with two parents, and $81 \%$ of lone-parent families are led by women (Statistics Canada, 2014). Low-income women-led families are more likely to be living in poverty and will find it harder to find a home they can afford.

Homelessness has continued to rise in the City and region. Low-income seniors, Indigenous households, single-parent households, people with disabilities or mental health, addiction challenges, and youth struggling with the housing crisis are at a greater disproportionate risk of homelessness. The 2019 City of Vancouver Homeless Count found 2,223 sheltered and unsheltered individuals experiencing homelessness, with Indigenous residents still disproportionately represented in comparison to their overall share in the population - 39\% compared with $2 \%$ (City of Vancouver, 2019d).

Vancouver's Indigenous residents are facing deeper inequities than elsewhere in the region, and so will experience the housing crisis more deeply than other resident groups. The average household income for Indigenous households in the City of Vancouver (2010) was approximately $20 \%$ lower than the Metro Vancouver Indigenous income average ( $\$ 55,500$ vs. $\$ 69,223$ ) and 31\% lower than the average non-Indigenous income in Vancouver (Statistics Canada, 2013).

\section{Responding to the Challenge: Housing Vancouver (2018-2027)}

Housing Vancouver is the City's ten-year housing strategy that was launched in 2017 as a response to the ongoing and intensive nature of Vancouver's housing crisis. It includes new approaches, tools and partnerships to ensure that Vancouver continues to support a diversity of incomes and households. Housing Vancouver was developed through discussions with key stakeholders and partners, with local and global housing leaders, and by talking to over 10,000 local residents. The strategy prioritizes the creation of new affordable homes and also measures to affect the housing market, so it works for a broader range of people who live and work in the City (City of Vancouver, 2019b). It is guided by the following key values:

- Diversity - Housing should respond to the diversity of people and households who call Vancouver home.

- Security - Housing is about 'homes first' and security of tenure, and is an important foundation to a sense of belonging in the City.

- Affordability - All residents should have access to housing options within their means that meet their needs.

- Connection - The right mix of homes supports resilient communities, with strong connections between people, places, and communities.

- Equity - Housing should promote equitable access to jobs, education, and other opportunities for economic prosperity for people of all ages, incomes, and backgrounds.

Building on these values, Housing Vancouver also identifies several key objectives:

- Shift towards the Right Supply: Make a significant shift towards rental, social, co-op, and supportive housing, as well as greater diversity of forms in Vancouver's ground-oriented housing stock. New homes must be accessible to the diversity of households who need housing.

- Action to Address Speculation and Support Equity: Address the impact of speculative demand on land and housing prices. Working together, partners and all levels of government to promote measures that advance equitable distribution of wealth gains from housing, learning 
lessons from around the world about addressing housing market pressures due to global flows of money, people, and jobs.

- Protect and Support Diversity: Take actions to protect and promote diversity of incomes, backgrounds, and household types across the City.

- Protect Our Existing Affordable Housing for the Future: Retain and preserve the affordability of the existing rental, co-op, and non-market homes, while balancing the need to renew and expand these buildings.

- Renew Our Commitment to Partnerships for Affordable Housing: New commitments by the City to new directions on affordable housing delivery, supporting and aligning with partners across all sectors, particularly non-profit, co-op, and Indigenous housing partners, and building partnerships with new stakeholders.

- Increase Supports and Protections for Renters and People who experience Homelessness: Address affordability, security of tenure, and the determinants of poverty and housing instability.

- Align City Processes with Housing Targets: Align policies, processes, and tools.

\section{Vancouver Is a City of Reconciliation}

Vancouver is located on the unceded territories of the Musqueam, Squamish, and TsleilWaututh Nations. Vancouver is strengthened by Indigenous culture and values, lived and practised by both on- and off-reserve Indigenous residents. The City has intensified its commitment to strengthening relationships with both on- and off-reserve Indigenous partners through its City of Reconciliation initiatives, recognizing the need for important shifts in how we work together moving forward. As a City of Reconciliation, Vancouver's key priority will be to address the disproportionate effect of intergenerational cycles of poverty, often including trauma and homelessness, within urban Indigenous communities.

The principles of reconciliation determine that urban Indigenous community should be involved at all stages of the housing design, delivery, development, and evaluation process, to ensure each step is respectful of the diverse needs of the urban Indigenous community. Indigenous culture, the importance of elders, and Indigenous healing can further support dynamic housing options that foster healing and wellness, through the provision of services which are integrated into the built form and design of the project. For example, space to accommodate childcare, resident elders, Indigenous healing programmes, and social programmes for tenants links to meaningful employment and tenant counselling services.

\section{The Right Supply Can Create More Housing Choices for Diverse Households}

A key response to housing affordability needs a focus on increasing housing supply. This is an obvious and critical part of any response to big city urban housing affordability challenges, but the key shift in Housing Vancouver from the previous housing strategy was that this new supply had to be the right supply and affordable to people who live and work in the City - new homes with a connection to local incomes, like market rental, co-op, and social housing, as well as a new supply that provided a more varied type of home, like low- and mid-rise apartments, townhouses, coach, and laneway homes. Core goals include retaining the diversity of incomes in the City, by shifting current housing production towards rental housing in order to respond to household need. Further, targets were set for new homes across a broad spectrum of households, including those with very low income.

The strategy identifies a target of 72,000 new homes, with $65 \%$ to be new rental homes. Almost half will be for households earning less than $\$ 80,000$ per year and $40 \%$ will be for 
families. Housing Vancouver quadrupled the previous target of purpose-built market rental, and it now stands at 20,000 homes, with 35\% for families. At least $20 \%$ will be privately owned rental homes, with below-market rents secured on some homes for the long-term. In addition, there is target of 4,000 rental laneway homes, with 50\% being suitable for families.

A significant amount of new homes will be below-market rental homes for individual households earning less than $\$ 50,000$ and for families earning less than $\$ 80,000$. Indeed, 12,000 new rental homes will be non-profit managed homes, including 2,000 new co-op homes and 4,100 homes with support, in order to meet the needs of lower-income households. This is a $50 \%$ increase from the previous strategy. The new social and supportive housing target will include homes for homeless individuals and vulnerable single-room occupancy (SRO) tenants currently living in inadequate housing and requiring supports.

\section{Location, Tenure, and Built Form of the Right Supply}

The location of new homes is critical, and they should be built near transit, jobs, key services, and amenities, such as community centres, schools, parks, and childcare. Higher growth corridors in the City are experiencing a growth in population, while lower density areas are seeing a decline in households, especially with families. The built form including height, density, and design has a direct impact on affordability of housing, who can live there, and how the building fits into existing neighbourhoods. A greater variety of built forms will be needed to accommodate diverse households, especially in lower density areas. The tenure of new homes is a strong determinant of who can afford to live there. Homes are needed across a broad continuum of income affordability and types, including social and co-op housing, below-market rental, market rental, and a diversity of ownership options. More recently, there has been proliferation of tenure options including rent-to-own models and co-housing.

\section{Maintaining Diversity by Achieving the Housing Vancouver Targets}

The City will make progress towards maintaining a diverse mix of households as a result of delivering on the ambitious Housing Vancouver targets, but none of this will happen without significant collaboration with private for-profit, non-profit, and government partners. An indication of the spread of affordability and new home types currently being delivered is depicted in Table 3.1. Social and supportive units did increase dramatically in 2017-2018. In terms of typology, the last five years have seen a steady increase in 1- and 3-bedroom units. For a full report on the latest progress on Housing Vancouver, refer to the Progress Report Dashboard 2019 (City of Vancouver, 2019a).

The City has key roles in creating the right supply, as an advocate, a regulator, and an investor, with the latter two being most significant. Some of the key strategies that optimize these roles and yield the right kind of supply are outlined below.

\section{City as a Regulator of New Diverse, Affordable Homes}

The City of Vancouver has a role in regulating land-use, which is critical when creating the right planning policy to increase the supply of rental homes (market, below-market, social, and co-op housing) along key transit corridors, which will improve access to jobs, schools, and community amenities for renters earning low and moderate incomes. The new Broadway Plan as and recently launched City-Plan are great opportunities for the City to identify areas around current and future transit hubs and corridors, as areas for growth and new rental homes, 
TABLE 3.1 Social and Supportive Housing Approvals in Vancouver, 2015-2019

\begin{tabular}{lllllllll}
\hline Year & Total Units & $\begin{array}{l}\text { Shelter Rate } \\
\text { Units (\%) }\end{array}$ & $\begin{array}{l}\text { HILs } \\
\text { Units (\%) }\end{array}$ & $\begin{array}{l}\text { LEM } \\
\text { Units (\%) }\end{array}$ & $\begin{array}{l}\text { Studio } \\
\text { Units (\%) }\end{array}$ & $\begin{array}{l}\text { 1-Bedroom } \\
\text { Units (\%) }\end{array}$ & $\begin{array}{l}\text { 2-Bedroom } \\
\text { Units (\%) }\end{array}$ & $\begin{array}{l}\text { 3-Bedroom } \\
\text { Units (\%) }\end{array}$ \\
\hline 2015 & 71 & 13 & 20 & 68 & 51 & 20 & 30 & 0 \\
2016 & 518 & 16 & 34 & 47 & 42 & 23 & 30 & 13 \\
2017 & 1,702 & 26 & 31 & 56 & 37 & 26 & 24 & 12 \\
2018 & 1,938 & 38 & 18 & 48 & 47 & 19 & 20 & 11 \\
2019 & 529 & 15 & 48 & 42 & 34 & 35 & 30 & 16 \\
\hline
\end{tabular}

Source: BC Housing, 2019; City of Vancouver, 2019a, 2019c; and Government of British Columbia, 2019.

a Housing Income Limits (HIL) refers to BC Housing's maximum gross household income limits, established annually by the Canada Mortgage and Housing Corporation. For Metro Vancouver Housing, these income limits represent the maximum annual household income threshold, before taxes, for Rent-Geared-to-Income tenants.

b Low-End-of-Market (LEM) refers to a type of subsidized housing where rent is calculated based on rental market conditions. For Metro Vancouver Housing, LEM rates are generally set between 10\% and 20\% below true market rental rates for comparable buildings (e.g. similar area, building age, and amenities). LEM units are intended for moderate income households who exceed the income thresholds for rent-geared-to-income housing but do not exceed the asset limit or income limit for LEM housing.

including both market and below-market options. In a paper on "Strengthening Economic Cases for Housing Policies", the researchers lay out clear benefits to the creation and subsidy of new homes in key locations in urban areas, including productivity and human capital gains, effective labour supply, and productive travel time savings, which justify government investment in new homes (Maclennan et al., 2019). Sites at and near current and future transit hubs and amenity-rich areas will be prioritized for new secured rental and social housing, including housing developed under new programmes that secure affordability in new market rental. Data on approval of new housing units in 2017-2018 indicate compliance with targets (over 107\%), with particularly strong performance in the category of housing for owners earning over $\$ 150,000$ / year (158\% of the two-year target) as well as in the renter/owner category of households earning $\$ 80,000-\$ 150,000$ per year (125\% of the two-year target). Most of the new housings in these two categories include higher density apartments and purpose-built rental (Table 3.2). Complementary City policies pertaining to intensification of residential areas through laneway housing have provided a boost to the affordable housing supply. The solutions for low-income renters are mostly through social housing, which is dependent on capital subsidies from senior levels of government and is relatively close to targets.

The Rental 100 Program, which has incentivized thousands of new market rental homes, is currently under review, and therefore presents an opportunity for further alignment with Housing Vancouver's objectives and targets. Vancouver's Moderate Income Rental Pilot is a new programme, wherein developments led by private for-profit developers secure a number of permanently affordable rental homes, targeted to households with annual incomes between $\$ 30,000$ and $\$ 80,000$. There are other Housing Vancouver goals that could lead to the transformation of low-density neighbourhoods by increasing the diverse supply of homes through a variety of housing types and affordable tenure options.

Housing Vancouver identifies the opportunity to include the right supply of homes into current and future planning policies, plans, and processes, including a review of Vancouver's Sustainable Large Sites Policy. Staff can consider moderate adjustments to height and density to enable more affordable homes to assist with affordability. The effective use of inclusionary housing policies has created a significant pipeline of new homes where the requirement was set out in a planning 
TABLE 3.2 Housing Units Approved, 2017-2018

\begin{tabular}{|c|c|c|c|c|c|c|c|c|}
\hline $\begin{array}{l}\text { Building } \\
\text { Type }\end{array}$ & Housing Type & Renter & Renter & Renter & Renter & $\begin{array}{l}\text { Renter E } \\
\text { Owner }\end{array}$ & Owner & $\begin{array}{l}\text { Total } \\
\text { Units }\end{array}$ \\
\hline Income & & $<\$ 15 \mathrm{~K} / \mathrm{yr}$ & $\$ 15-30 \mathrm{~K} / \mathrm{yr}$ & $\$ 30-50 \mathrm{~K} / \mathrm{yr}$ & $\$ 50-80 \mathrm{~K} / \mathrm{yr}$ & $\$ 80-150 \mathrm{~K} / \mathrm{yr}$ & $>\$ 150 \mathrm{~K} / \mathrm{yr}$ & \\
\hline Apartment & $\begin{array}{l}\text { Supportive and } \\
\text { social }\end{array}$ & 962 & 85 & 776 & 1,206 & 611 & & 3,640 \\
\hline Apartment & $\begin{array}{l}\text { Purpose-built } \\
\text { rental }\end{array}$ & & & 0 & 957 & 896 & & 1,853 \\
\hline Apartment & Condos & & & & 765 & 4,290 & 3,282 & 8,338 \\
\hline Infill & Laneways & & & & 608 & 692 & & 1,300 \\
\hline Infill & Coach houses & & & & & 0 & 0 & 0 \\
\hline Townhouses & Townhouses & & & & & 89 & 186 & 275 \\
\hline \multirow[t]{3}{*}{ Units } & Total (2017-2018) & 962 & 85 & 776 & 3,536 & 6,578 & 3,469 & 15,406 \\
\hline & Two-year target & 1,040 & 320 & 900 & 4,700 & 5,240 & 2,200 & 14,400 \\
\hline & $\begin{array}{l}\text { Percentage of } \\
\text { two-year } \\
\text { target }\end{array}$ & 93 & 27 & 86 & 75 & 126 & 158 & 107 \\
\hline
\end{tabular}

Source: City of Vancouver, 2019c.

policy or district schedule, and the City secured new homes and/or an air-space parcel through a rezoning or development permit process. These homes are then leased long-term to nonprofit or co-op housing providers, who offer a range of affordable rent to diverse households. Currently, around 2,500 homes towards the 12,000 new social and supportive Housing Vancouver target are being delivered through this stream.

It is not just the number and affordability of homes that is important when considering mix and diversity. Design principles that build homes that meet the needs of Vancouver's diverse households and populations are vital, including incorporating design principles for family-oriented, co-housing, seniors, and accessible housing, and emerging Indigenous housing design principles. Ideally, new rental homes should be accompanied by key services and supports for people and households with intersecting housing, childcare, health, and economic needs and challenges. Housing Vancouver also recognizes that simplifying city regulations and reducing approval times is a clear contribution that the City makes to the delivery of affordable rental housing.

\section{City as an Investor in Diversity}

The purchase and provision of City land has been a successful and long-standing approach to create new affordable homes and leverage investments from both non-profit and government partners. The City set up the Vancouver Affordable Housing Agency (VAHA) to oversee the acquisition and development of new affordable homes on its land. VAHA currently has around 2,500 homes in various stages of development and construction, and is also now in the process of creating the Vancouver Affordable Housing Endowment Fund (VAHEF), which will bring together all the City's affordable housing and land assets together in one portfolio to streamline the management and improve housing outcomes. Many of the new homes in development have brought in equity and financing from the provincial and federal governments, and they are being developed in partnership with the community housing sector. 
In addition to the use of City land for new affordable housing supply, the City is also a director/investor of capital grants into the community housing sector, where they are developing new affordable homes on their own land. The City of Vancouver has been offering capital grants between $\$ 10,000$ and $\$ 30,000$ per home, but due to the rising costs of construction, the need to address equity imbalances, and greater affordability being targeted in Housing Vancouver, this grant programme is currently under review.

\section{Preserving Existing Homes}

A backdrop to the current drive to maintain diversity is through existing rental homes, including social and co-op housing, sometimes on City land, where it will be important to balance the need to prioritize reinvestment and affordability with opportunities to expand the number of affordable homes. The City has a critical role in these opportunities. It remains essential to engage with the federal government on key housing issues relating to supporting critical repairs, reinvestment, and renewal of housing subsidies for existing affordable housing through Canada's Housing Strategy. This includes the implementation of programmes that dedicate funding to urgent repairs in social and co-op housing.

\section{Supportive Housing Is a Positive Contribution to Diverse Communities}

A home is a primary factor for individuals experiencing homelessness in supporting the move forward towards balance and healing. The delivery of Housing First supportive housing is the practice of offering independent, permanent housing to those individuals experiencing homelessness, and then providing support. Supportive housing options across all communities in Vancouver provide access to those experiencing homelessness, along with mental, physical, and addiction challenges, so that they become housed in the communities they are living in or have a strong connection to. In 2019, the City of Vancouver, in partnership with BC Housing, completed phase one of a Rapid Response to Homelessness programme, including 600 new temporary modular supportive homes in 13 buildings across ten different sites in Vancouver, with supports provided by experienced non-profit housing providers. One of these buildings prioritizes black and Indigenous residents, two of them are managed in partnership with an Indigenous housing provider, and another two projects prioritize women with experience of homelessness. The partners are currently working together on phase two.

\section{Conclusion}

The threat of Vancouver's housing crisis on diversity has required the City to take significant actions in its housing strategy. The intersection between housing affordability challenges and marginalization, including gender and sexual identity, race, poverty, family status, and mental and physical health, has become a powerful force limiting the future of inclusion, diversity, and mixed communities in Vancouver. While mixed-income communities have long been a policy focus, Housing Vancouver has a broader focus on diversity and looks to provide a fuller range of new affordable homes that can better meet the needs of those who live and work in Vancouver. There is more work to be done to implement this strategy with partners like the community housing sector, more support needed from provincial and federal governments, and more bold steps by the City, if we are to keep Vancouver's diversity and enable it to be home to individuals and families from different incomes and backgrounds. 


\section{Acknowledgements}

This chapter is based on the City of Vancouver's latest housing strategy, Housing Vancouver (2018-2027), and so it is important to acknowledge all the City of Vancouver's councilors, staff, partners, stakeholders, and public who contributed during the year-long process of convening and testing new ideas and approaches to addressing housing affordability in Vancouver. https:// council.vancouver.ca/20171128/documents/rr1appendixa.pdf

Special thanks to Dr Tsenkova for the organization of the international symposium on partnerships for affordable housing and for her assistance with the chapter presenting Vancouver's experience.

\section{References}

BC Housing (2019). "BC Housing 2019 Housing Income Limits (HILs)”. Website accessed October 2019, www.bchousing.org/publications/2019-Housing-Income-Limits-HILs.pdf

Canada Mortgage and Housing Corporation (CMHC) (2016a). "Rental Market Report - British Columbia Highlights". Website accessed October 2019, https://eppdscrmssa01.blob.core.windows.net/

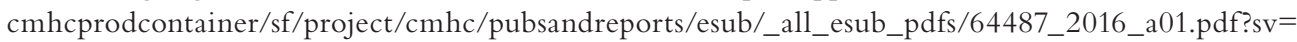
$2018-03-28 \& s s=b \& s r t=s c o \& s p=r \& s e=2021-05-07 T 03: 55: 04 Z \& s t=2019-05-06 \mathrm{~T} 19: 55:$ 04Z\&spr=https,http\&sig=bFocHM6noLjK8rlhy11dy\%2BkQJUBX\%2BCDKzkjLHfhUIU0\%3D

CHMC (2016b). "Rental Market Report - Vancouver CMA". Website accessed October 2019, https:// eppdscrmssa01.blob.core.windows.net/cmhcprodcontainer/sf/project/cmhc/pubsandreports/ esub/_all_esub_pdfs/64467_2016_a01.pdf?sv $=2018-03-28 \& s s=b \& s r t=s c o \& s p=r \& s e=2021-05-$ 07T03:55:04Z\&st=2019-05-06T19:55:04Z\&spr=https,http\&sig=bFocHM6noLjK8rlhy11dy\%2BkQJUBX\%2BCDKzkjLHfhUIU0\%3D

Chisholm, S., and Hulchanski, D. (2019). "Canada's Housing Story”, in D. Maclennan, H. Pawson, K. Gibb, S. Chisholm and D. Hulchanski (eds)., Shaping Futures Changing the Housing Story Final Report. Glasgow: Policy Scotland, University of Glasgow, p. 27.

City of Vancouver (2019a). "City of Vancouver Progress Report Dashboard 2019 - Q3 Update”. Website accessed October 2019, https://vancouver.ca/files/cov/2019-housing-vancouver-dashboard.pdf

City of Vancouver (2019b). "Housing Vancouver Strategy". Website accessed October 2019, https:// council.vancouver.ca/20171128/documents/rr1appendixa.pdf

City of Vancouver (2019c). "Housing Vancouver Strategy: Annual Progress Report and Data Book 2019”. Website accessed October 2019, https://vancouver.ca/files/cov/2019-housing-vancouver-annualprogress-report-and-data-book.pdf

City of Vancouver (2019d). "Vancouver Homeless Count 2019”. Website accessed October 2019, https:// vancouver.ca/files/cov/vancouver-homeless-count-2019-final-report.pdf

Generation Squeeze (2019). "Straddling the Gap: A Troubling Portrait of Home Prices, Earnings and Affordability for Younger Canadians". Website accessed October 2019, https://d3n8a8pro7vhmx. cloudfront.net/gensqueeze/pages/5293/attachments/original/1560279096/Straddling-the-Gap2019_final.pdf?1560279096

Government of British Columbia (2019). "Shelter Component of Income Assistance - Income Assistance Rate Table". Website accessed October 2019, www2.gov.bc.ca/gov/content/governments/policiesfor-government/bcea-policy-and-procedure-manual/bc-employment-and-assistance-ratetables/income-assistance-rate-table

Maclennan, D. with: Randolph, B., Crommelin, L., Witte, E., Klestov, P., Scealy, B., and Brown, S. (2019). Strengthening Economic Cases for Housing Policies. Sydney: City Future Research Centre UNSW Built Environment, UNSW Sydney, pp. 24-25.

Statistics Canada (2013). Vancouver, CY, British Columbia (Code 5915022) (Table). National Household Survey (NHS) Profile. 2011 National Household Survey. Statistics Canada Catalogue no. 99-004-XWE. Ottawa. Website accessed October 4, 2019, www.12.statcan.gc.ca/nhs-enm/2011/dp-pd/prof/index. cfm?Lang=E 
Statistics Canada (2014). Lone-parent Families. Ottawa: Statistics Canada. Website accessed April 16, 2021, www150.statcan.gc.ca/n1/pub/75-006-x/2015001/article/14202/parent-eng.htm

Statistics Canada (2017a). Vancouver, CY [Census subdivision], British Columbia and Greater Vancouver, RD [Census Division], British Columbia (Table). Census Profile. 2016 Census. Statistics Canada Catalogue no. 98316-X2016001. Ottawa. Website accessed October 4, 2019, www12.statcan.gc.ca/census-recensement/ 2016/dp-pd/prof/index.cfm?Lang=E

Statistics Canada (2017b). Vancouver [Census Metropolitan Area], British Columbia and Greater Vancouver, RD [Census Division], British Columbia (Table). Census Profile. 2016 Census. Statistics Canada Catalogue no. 98316-X2016001. Ottawa. Website accessed October 4, 2019, www12.statcan.gc.ca/census-recensement/ 2016/dp-pd/prof/index.cfm?Lang=E 